\title{
A mixed ration of crop residues: effects on rumen fermentation characteristics and blood indices of West African dwarf sheep
}

${ }^{1 *}$ Omotoso, S. O., Ajayi, F. T., Boladuro, B. A. and Emerue, P. C.

Institute of Agricultural Research and Training, Obafemi Awolowo University,

Moor Plantation, Ibadan.

Abstract

*Corresponding author:tobsum2006@gmail.com; +234 8060838357

Crop residues are potential supplementary feed of small ruminants in Nigeria. However, arbitrary feeding of crop residues without due consideration to proportions and nutritive values could result in poor performance. Information on the proportions of mixed ration of different roughage sources for sheep is limited. Therefore, the effect of mixed ration of crop residues on the rumen fermentation and blood profiles of West African dwarf (WAD) sheep was investigated. Sixteen female WAD sheep with an average live weight of $8.10 \pm 0.16 \mathrm{~kg}$ were used in a completely randomised design with four animals per treatment. Experimental diets (1 to 4) constitutes 53\% each of corn cob, cassava peel, groundnut haulm and cowpea husk respectively, with 30\% palm kernel sludge, $12 \%$ soya bean hull, 4.5\% Gliricidia sepium, and $0.5 \%$ salt across each diet. The results revealed non-significant $(p>0.05)$ effects of experimental diets on rumen $\mathrm{pH}$ and volatile fatty acids. Rumen ammonia nitrogen differed significantly $(p<0.05)$, with the highest $(10.17 \mathrm{mg} / 100 \mathrm{~mL})$ and lowest $(8.51 \mathrm{mg} / 100 \mathrm{~mL})$ values in sheep fed dietary treatments 4 and 2, respectively. Bacteria counts were highest $\left(1.75 \mathrm{cfu} / \mathrm{mLx} 10^{5}\right)$ in sheep fed diet 4 and lowest $\left(1.28 \times 10^{5} \mathrm{cfu} / \mathrm{mL}\right)$ in sheep fed diet 3 . Rumen fungi and protozoa counts were similar $(p>0.05)$ among treatment groups. Packed cell volume, haemoglobin, and red blood cell counts were highest $(52.00 \%, 16.95 \mathrm{~g} / \mathrm{dL}$ and 14.25 $\left.x 10^{6} / \mu \mathrm{L}\right)$ for sheep fed diet 4 and lowest $\left(33.00 \%, 10.65 \mathrm{~g} / \mathrm{dL}\right.$ and $\left.11.79 \times 10^{6} / \mu \mathrm{L}\right)$ in sheep fed diet 1 . While the white blood cell was significantly $(p<0.05)$ highest $\left(8.43 \times 10^{3} / \mu l\right)$ in sheep fed diet 2, lymphocytes and neutrophils counts were similar $(p>0.05)$ among treatments. Serum biochemical components were significantly different $(p<0.05)$ among the treatments, except aspartate aminotransferase and creatinine. In conclusion, utilization of mixed ration of crop residues as feed did not compromise ruminal activities and the health of WAD sheep.

Keywords: Haematology and serum, roughage mixtures, rumen fermentation, sheep

\section{Une ration mixte de résidus de culture : effets sur les caractéristiques de fermentation du rumen et les indices sanguins des moutons de West AfricanDwarf}

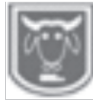

Résumé

Les résidus de récolte sont des aliments complémentaires potentiels pour les petits ruminants au Nigeria. Cependant, une alimentation arbitraire des résidus de culture sans tenir dûment compte des proportions et des valeurs nutritives pourrait entraîner de mauvaises performances. Les informations sur les proportions de ration mixte de différentes sources de fourrage pour les moutons sont limitées. Par conséquent, l'effet d'une ration mixte de résidus de récolte sur la fermentation du rumen et les profils sanguins de moutons West AfricanDwarf (WAD) a été étudié. Seize moutons WAD femelles d'un poids vif moyen de 8,10 $\pm 0,16 \mathrm{~kg}$ ont été utilisés dans une conception complètement randomisée avec quatre animaux par traitement. Les régimes expérimentaux (1 à 4) contiennent respectivement $53 \%$ de rafle de maïs, d'écorce de manioc, de fane d'arachide et de cosse de niébé, avec $30 \%$ de 


\section{A mixed ration of crop residues}

boue de palmiste, $12 \%$ de coque de soja, 4,5\% de Gliricidiasepium et 0,5\% de sel dans chaque régime. . Les résultats ont révélé des effets non significatifs $(p>0,05)$ des régimes expérimentaux sur le $\mathrm{pH}$ du rumen et les acides gras volatils. L'azote ammoniacal du rumen différait significativement ( $p<0,05)$, avec les valeurs les plus élevées $(10,17 \mathrm{mg} / 100 \mathrm{ml})$ et les plus faibles $(8,51 \mathrm{mg} / 100 \mathrm{ml})$ chez les moutons nourris avec les traitements diététiques 4 et 2, respectivement. Le nombre de bactéries était le plus élevé (1,75 cfu/mL x 105) dans le régime 4 des moutons et le plus bas $(1,28 \times 105 \mathrm{cfu} / \mathrm{mL})$ dans le régime 3 . Le nombre de champignons et de protozoaires du rumen était similaire $(p>0,05)$ parmi les groupes de traitement. L'hématocrite, l'hémoglobine et le nombre de globules rouges étaient les plus élevés $(52,00 \%, 16,95 \mathrm{~g} / \mathrm{dL}$ et 14,25 $1106 / \mu \mathrm{L})$ pour les moutons nourris avec le régime 4 et les plus bas $(33,00 \%, 10,65 \mathrm{~g} / \mathrm{dL}$ et $11,79 \times 106 / \mu \mathrm{L})$ chez les moutons régime alimentaire 1.Alors que le nombre de globules blancs était significativement $(p<0,05)$ le plus élevé $(8,43$ $x$ 103/ $/ \mathrm{ll}$ ) chez les moutons nourris avec le régime 2, le nombre de lymphocytes et de neutrophiles était similaire $(p>0,05)$ parmi les traitements. Les composants biochimiques $d u$ sérum étaient significativement différents $(p<0,05)$ parmi les traitements, à l'exception de l'aspartateaminotransférase et de la créatinine. En conclusion, l'utilisation d'une ration mixte de résidus de culture comme aliment n'a pas compromis les activités ruminales et la santé des moutons WAD.

Mots clés : Hématologie et sérum, mélanges de fourrages grossiers, fermentation ruminale, mouton

\section{Introduction}

Crop residues and agro-industrial byproducts are alternate feed resources often utilized to salvage dry season feed challenges in ruminant production systems particularly in the Southwest agro-ecology zones of Nigeria. However, arbitrary feeding of crop residues as a supplement to ruminants in confinement by smallholder farmers without due consideration to the proportions and nutritive values could result in poor health status and performance. About $40-60 \%$ of the total dry matter intake of ruminants is from crop residues (Rao and Hall, 2003) but dietary nutrient utilization efficiency for growth, production or maintenance is limited. Reasons are because of the high fibre ( $>$ $40 \%)$, low protein $(<60 \mathrm{~g} / \mathrm{kg} \mathrm{DM})$, low essential macro and micro minerals and low metabolizable energy $(<7.5 \mathrm{MJ} / \mathrm{kgDM})$ contents (Tingshuang et al., 2002; Gulilat and Chekol, 2020). Nevertheless, methods of enhancing the effective utilization of fibres in crop residues-based diets by ruminants have been documented (Adesogan et al., 2019). In-vivo and in-vitro trials of tropical crop residues have shown higher organic matter digestibility and lower methane emission (Aregheore, 2000; Bhatt et al., 2014) by small ruminants. Roughage diets from crop residues provide bulk for proper rumen function and fermentation of the fibres into useful volatile fatty acids components; a source of energy for rumen microbes and the host ruminants (Bergman, 1990; Nathani et al., 2015). Cassava peel, cowpea husk, groundnut haulm and corncob amongst others are notable crop residues widely utilized as low-cost roughage diets for small ruminants compared to the highly expensive grain-based concentrates. When any of these feed resources are ingested by small ruminants their physiological disposition to dietary nutrients can be evaluated via blood profiles. Similarly, the patterns of fermentation in the rumen vis-àvis microbiota activities are plausible indicators of the efficiency or inefficiency of dietary nutrients for maintenance or production and overall health of the "host". According to Konka et al. (2016), crop residue-based complete ration in ruminant 
feeding systems stabilizes ruminal fermentation, minimize fermentation losses and promotes the efficiency of ammonia utilization. Consequent to the arbitrary feeding of small ruminants with crop residues by smallholder farmers in Nigeria, rumen fermentation and blood profiles assays are necessary to diagnose the health status of animals reared under intensive husbandry systems. Therefore, a study was conducted to determine the effects of feeding different sources of roughages namely corn cob, cassava peel, groundnut haulms and cowpea husk on rumen fermentation, haematological and serum biochemical profiles of West African dwarf sheep.

\section{Materials and methods}

\section{Location of study and animal management}

The experiment was carried out at the sheep and goat unit of the Institute of Agricultural Research and Training, Moor Plantation, Ibadan, Nigeria (latitude $7^{\circ} 15^{\prime}$ to $7^{\circ} 30^{\prime}$ North and longitude $3^{\circ} 45^{\prime}$ to $4^{\circ} 0^{\prime}$ East). The area has a tropical humid climate with a mean annual rainfall of $1415 \mathrm{~mm}$ and an average daily temperature of 28 and $35^{\circ} \mathrm{C}$. Before the commencement of the experiment, animals were given prophylactic treatments against ecto and endo-parasites. The animals were adapted to their treatment diets over a 2-week preliminary period, which was followed by a 105-day feeding trial. Sixteen West African Dwarf (WAD) female sheep with an average live weight of $8 \pm 0.16 \mathrm{~kg}$ were weighed and randomly allotted to individual pens and one of four (4) treatment diets in a completely randomized design with four animals per treatment.

Experimental diets and feeding of animals Dried cowpea husk, groundnut haulm, soya bean hull, cassava peel and corn cob were obtained from feedstuff vendors and crop processing unit of the Institute of
Agricultural Research and Training, Ibadan. Gliricidia sepium leaves were harvested fresh from an established pasture and air-dried under shade to about 25\% dry matter. Four experimental diets were compounded to include each ingredient (Table 1) as follows; Diet $1=(53 \%$ Dried corn cob, 30\% Palm kernel sludge, 12\% Soya bean hull, $4.5 \%$ Gliricidia sepium and $0.5 \%$ Salt $)$, Diet $2=(53 \%$ Dried cassava peel, 30\% Palm kernel sludge, 12\% Soya bean hull, 4.5\% Gliricidia sepium and 0.5\% Salt $)$, Diet 3 $=(53 \%$ Groundnut haulm, 30\% Palm kernel sludge, 12\% Soya bean hull, $4.5 \%$ Gliricidia sepium and $0.5 \%$ Salt) and Diet $4=(53 \%$ Cowpea husk, 30\% Palm kernel sludge, 12\% Soya bean hull, 4.5\% Gliricidia sepium and $0.5 \%$ Salt). Crop residue mixtures (Diet 1 to Diet 4 ) were offered separately to individual animals at $3 \%$ body weight at $08: 00 \mathrm{~h}$. Unripe plantain peels were offered to all the sheep at $2 \%$ of their body weight at 16:00h. Provision was made for a daily feed allowance of $10 \%$ above the previous week's consumption. Clean water was served ad libitum.

\section{Collection of rumen liquor samples and analysis}

At the end of the experiment, rumen fluid samples (about $100 \mathrm{~mL}$ ) were collected from the rumen of each sheep using stomach tubes into sterile sample bottles as described by Babayemi and Bamikole (2006) at $4 \mathrm{~h}$ post-feeding. The $\mathrm{pH}$ of the rumen fluid was recorded immediately after collection using a digital $\mathrm{pH}$ meter (3510 model $\mathrm{pH}$ meter, Jenway, UK). The rumen liquor was strained through 4 layers of sterile cheesecloth for separation of the liquid and solid fractions without any wash. The liquid fraction was divided into two portions. The first portion of the strained rumen fluids was acidified with $0.2 \mathrm{~mol} / \mathrm{L}$ HCL solution and kept in labelled sample bottles stored at $-20^{\circ} \mathrm{C}$ till required for volatile fatty acids and rumen ammonia nitrogen analysis. The second portion of the 
rumen fluid was fixed with $10 \%$ formalin solution (1:9 v/v, rumen fluid: $10 \%$ formalin) and immediately kept in ice and stored at $-20{ }^{\circ} \mathrm{C}$ till further analyses of the microbial population. Rumen ammonia nitrogen $\left(\mathrm{NH}_{3}-\mathrm{N}\right)$ concentration was determined by steam distillation and absorption in boric acid solution and later by titration with $0.1 \mathrm{~N} \mathrm{H}_{2} \mathrm{SO}_{4}$. Volatile fatty acids (VFA) concentrations were analyzed according to the procedure of Gilchrist (1967). Microbial population in the rumen fluids was by total direct count of bacteria, protozoan and fungal zoospores as described by Galyean (1989) and Dehority (2003).

\section{Collection of blood samples and analysis}

At the end of the experiment, two sets of blood samples (approximately 10mLs) were collected from each sheep before feeding through a jugular vein puncture using a $10 \mathrm{~mL}$ syringe fitted with a hypodermic needle. Blood $(5 \mathrm{mLs})$ was drawn into labelled heparinized tubes to prevent coagulation for the determination of haematological parameters while the remaining $5 \mathrm{mLs}$ was drawn into anticoagulant free bottles, allowed to coagulate at room temperature and centrifuged for 5 $\mathrm{min}$ at $3000 \mathrm{rpm}$ for serum analysis. The supernatant sera were then stored in a freezer for subsequent biochemical analysis. The packed cell volume (PCV) was estimated by the method of Jain (1993), and haemoglobin $(\mathrm{Hb})$ concentration according to the method of Schalm et al. (1975). Red blood cell (RBC), total white blood cell count (WBC) and differential WBC counts were determined using the Neubauer hemocytometer counting chamber. (MCHC) was calculated from $\mathrm{RBC}, \mathrm{Hb}$ and PCV values as described by Dacie and Lewis (2001). Serum total protein was determined using the biuret method as described (Kohn and Allen, 1995). Albumin and globulin were determined using the bromocresol purple method of Varley et al. (1980). Blood urea nitrogen and glucose were determined by an enzymatic colourimetric method (Helmut and Yvette, 1959) and the spectrophotometer was read at wavelengths of $550 \mathrm{~nm}$ and $600 \mathrm{~nm}$, respectively. Creatinine was determined by the method of Bonsnes and Taussky (1945) while cholesterol was determined by the method of Allain et al. (1974). Alanine Aminotransferase (ALT), Aspartate Aminotransferase (AST) and Alkaline Phosphatase (ALP) were analyzed spectrophotometrically by using commercially available diagnostic kits (Randox ${ }^{\circledR}$ Test Kits).

\section{Chemical analysis offeed}

Dried samples of the experimental diets and unripe plantain peel were analyzed for the proximate composition according to the standard procedures (AOAC, 2000). Neutral detergent fibre, acid detergent fibre and Acid detergent lignin were determined according to the procedure of Van Soest et al. (1991). Metabolisable energy (ME) was estimated according to De Boever et al. (1997) equation as follows: $\mathrm{ME}=12.86+$ 0.0265 EE- 0.0056 ADF - 0.0153 ASH 0.0253 ADL. Where EE = ether extract, $\mathrm{ADF}=$ acid detergent fibre and $\mathrm{ADL}=$ acid detergent lignin.

\section{Statistical analyses}

Data obtained were subjected to analysis of variance for a completely randomized design using the general linear model (PROC GLM) of SAS (1999). The least significant difference (LSD) statistics were used to identify differences among means. Differences among means were considered significant at a probability level of $\mathrm{p}<0.05$.

\section{Results and discussion}

Table 2 shows the chemical composition of the experimental diets. The dry matter (DM) and crude protein (CP) contents were highest (89.43 and $17.33 \mathrm{~g} / 100 \mathrm{~g} \mathrm{DM})$ in diet 4 and lowest $(86.11$ and $5.20 \mathrm{~g} / 100 \mathrm{~g}$ 
DM)in diet 1. Except for the CP content of diet $1(5.20 \mathrm{~g} / 100 \mathrm{~g} \mathrm{DM})$, the range of CP (14.82-17.33g/100g DM) of diets 2 to 4 exceeded the CP level for sheep (NRC, 2007). Broken grains tightly held within the cowpea husk could have contributed to the higher (17.33 g/100g DM)CP contentobserved in diet 4 . The ether extract ranged from 1.06 to $3.66 \mathrm{~g} / 100 \mathrm{~g}$ DM.The ether extracts (1.06 to $3.66 \mathrm{~g} / 100 \mathrm{~g} \mathrm{DM})$ values of experimental diets in this study, which are below the range of 5-6\% dietary fat that could negatively affect rumen microbial activity (Kucuk et al., 2003)are suggestive of being able to promote optimal ruminal fermentation activities. The fibre fractions (NDF, ADF and ADL) were highest $(69.86,48.94$ and $17.43 \mathrm{~g} / 100 \mathrm{~g} \mathrm{DM})$ in diet 1 and lowest $(58.44,41.35$ and $12.67 \mathrm{~g} / 100 \mathrm{~g} \mathrm{DM})$ in diet 3 . The mean values of $\mathrm{NDF}(65.04 \mathrm{~g} / 100 \mathrm{~g} \mathrm{DM})$ of experimental diets though were above the range $(55-60 \mathrm{~g} / 100 \mathrm{~g} \mathrm{DM})$ reported to limit feed intake (Meissner and Paulsmeier, 1995), the high fibre fractions of feed particle could also facilitate colonization of ingesta by rumen microbes to increase the rate of degradability (Klopfenstein et al., 2001).

Table 1: Ingredient composition of experimental diets

\begin{tabular}{lllll}
\hline & \multicolumn{4}{c}{ Dietary roughage treatments } \\
\cline { 2 - 5 } Ingredients (\%) & Diet 1 & Diet 2 & Diet 3 & Diet 4 \\
\hline Dried corn cob & 53.0 & ---- & ----- & ---- \\
Palm kernel sludge & 30.0 & 30.0 & 30.0 & 30.0 \\
Soya bean hull & 12.0 & 12.0 & 12.0 & 12.0 \\
Dried cassava peel & ----- & 53.0 & ----- & ----- \\
Groundnut haulm & ---- & ---- & 53.0 & ---- \\
Cowpea husk & ---- & ---- & ----- & 53.0 \\
Gliricidia sepium & 4.5 & 4.5 & 4.5 & 4.5 \\
Salt & 0.5 & 0.5 & 0.5 & 0.5 \\
\hline
\end{tabular}

Table 2: Chemical composition (g/100g DM) of experimental diets and unripe plantain peel

\begin{tabular}{|c|c|c|c|c|c|}
\hline \multirow[b]{2}{*}{ Nutrients } & \multicolumn{4}{|c|}{ Dietary roughage treatments } & \multirow[b]{2}{*}{ Unripe plantain peel } \\
\hline & Diet 1 & Diet 2 & Diet 3 & Diet 4 & \\
\hline Dry matter & 86.11 & 88.50 & 88.35 & 89.43 & 87.17 \\
\hline Crude protein & 5.20 & 15.34 & 14.82 & 17.33 & 5.42 \\
\hline Ash & 5.78 & 4.71 & 4.30 & 5.90 & 4.37 \\
\hline Ether extract & 1.06 & 2.94 & 2.85 & 3.66 & 3.20 \\
\hline Neutral detergent fibre & 69.86 & 62.91 & 58.44 & 68.95 & 51.37 \\
\hline Acid detergent fibre & 48.94 & 43.06 & 41.35 & 47.81 & 39.57 \\
\hline Acid detergent lignin & 17.43 & 13.35 & 12.67 & 15.08 & 11.44 \\
\hline $\begin{array}{l}\text { Metabolizable energy } \\
\text { (MJ/kg DM) }\end{array}$ & 12.12 & 12.29 & 12.27 & 12.22 & 12.37 \\
\hline \multicolumn{6}{|c|}{$\begin{array}{l}\text { Diet } 1=53 \% \text { Dried corn cob, } 30 \% \text { Palm kernel sludge, } 12 \% \text { Soya bean hull, } 4.5 \% \text { Gliricidia sepium } \\
\text { and } 0.5 \% \text { Salt; Diet } 2=53 \% \text { Dried cassava peel, } 30 \% \text { Palm kernel sludge, } 12 \% \text { Soya bean hull, } 4.5 \% \\
\text { Gliricidia sepium and } 0.5 \% \text { Salt; Diet } 3=53 \% \text { Groundnut haulm, 30\% Palm kernel sludge, } 12 \% \text { Soya } \\
\text { bean hull, } 4.5 \% \text { Gliricidia sepium and } 0.5 \% \text { Salt; Diet } 4=53 \% \text { Cowpea husk, } 30 \% \text { Palm kernel sludge, } \\
12 \% \text { Soya bean hull, } 4.5 \% \text { Gliricidia sepium and } 0.5 \% \text { Salt. }\end{array}$} \\
\hline
\end{tabular}




\section{A mixed ration of crop residues}

Rumen fermentation characteristics and microbial population

Presented in Table 3 are the results of rumen fermentation characteristics and microbial population of sheep fed mixed ration of crop residues. The rumen $\mathrm{pH}$ showed no significant $(\mathrm{p}>0.05)$ difference across the treatments. Observed rumen $\mathrm{pH}$ values (6.05 to 6.20) in this study are within the normal pH range of 5.5 to 7.0 (Krause and Oetzel, 2006) considered as appropriate for microbial digestion of fibre and proteins in ruminants largely fed roughages. Consumption of high levels of dietary fibres by ruminants increases the buffering capacity of the rumen due to stimulation of saliva production in the buccal cavity (Kohn and Dunlop, 1998; Aschenbach et al., 2011). The experimental diets in this study, being highly fibrous could have stimulated constant salivation during rumination to produce bicarbonates and phosphates into the rumen for maintenance of optimal ruminal $\mathrm{pH}$ in the experimental animals. Ammonia nitrogen concentration in the rumen is a function of protein quality and its degradability. The rumen ammonia nitrogen $\left(\mathrm{NH}_{3}-\mathrm{N}\right)$ concentration obtained in this trial ranged from 8.51 to 10.17 $\mathrm{mg} / 100 \mathrm{~mL}$. Significantly $(\mathrm{p}<0.05)$ highest rumen $\mathrm{NH}_{3}-\mathrm{N}$ concentration (10.17 $\mathrm{mg} / 100 \mathrm{~mL}$ ) observed in sheep fed diet 4 may be linked with the high crude protein content of the diet (Table 2) and crude protein digestibility (Ajayi et al., 2019), probably due to a more functional rumen that allowed rapid ruminal fermentation of dietary proteins. As a qualitative reference for the detection of microbial activity in structural carbohydrates in the rumen (Detmann et al., 2009), Leng (1990) reported that ruminal $\mathrm{NH}_{3}-\mathrm{N}$ concentrations of $5-20 \mathrm{mg} / 100 \mathrm{~mL}$ are required for enhanced microbial activity and digestion by ruminants fed poor quality roughages or fibrous feed. It could be inferred that ruminal $\mathrm{NH}_{3}-\mathrm{N}$ concentrations (8.51-10.17 $\mathrm{mg} / 100 \mathrm{~mL}$ ) observed in this study fell within the range of $5-20 \mathrm{mg} / 100 \mathrm{~mL}$ (Leng, 1990), thus were adequate for ruminal fermentation activities. The concentrations of total volatile fatty acids (TVFAs), acetic, propionic and butyric acids were similar ( $>0.05)$ across the treatments. Meanwhile, TVFAs, acetic, propionic and butyric acid values were highest in sheep fed diet 4 and lowest in sheep fed diet 1 . The fermentable carbohydrates of the principal ingredients (cassava peel and cowpea husk) in diets 2 and 4 respectively, could have attributed to the higher values of TVFAs observed in sheep fed the respective diets. Meanwhile, the highest concentration of TVFA, acetic, propionic and butyric acids observed in sheep fed diet 4 compared to other treatments further indicates the higher degradability potential of the nutrients. The proportions of VFAs in this study disagreed with the findings of Firkins et al. (2006) who reported a higher concentration of acetic acid and a low amount of propionic and butyric acids in the rumen for high fibre diets. The non-significance of ruminal VFAs concentrations across the treatments may be ascribed to dietary fibre components (e.g. Neutral detergent fibre), substrate composition, specific types of rumen microbes to degrade the diets consumed (Haddad and Grant, 2000) and the rumen $\mathrm{pH}$ values which favour bacterial adherence for enhanced digestion of fibres (Palmonari et al., 2010). Except for sheep fed diet 2, the higher concentration of butyric acid relative to acetic and propionic acids suggest nutrient utilization efficiency (Li et al., 2012), which may have impacted positively on the growth performance of the sheep (Ajayi et al., 2019). Although specific butyrate-producing bacteria or protozoa species were not identified, higher rumen butyric acid concentration relative to acetic and propionic acids in this study are associated with protozoa counts. This agreed with the findings of Carberry et al. 
(2006) who reported that ruminal protozoa populations have a positive relationship with the levels of butyric acid. Total bacteria counts were significantly highest $\left(1.75 \mathrm{cfu} / \mathrm{mLx} 10^{5}\right)$ in sheep fed diet 4 and lowest $\left(1.28 \times 10^{5} \mathrm{cfu} / \mathrm{mL}\right)$ in sheep fed diet 3. Corn cob and cowpea husk (major roughage components of diets 1 and 4 , respectively) though very high in fibre, arehighly fermentable structural carbohydrates which when ruminally degraded could have resulted in the higher bacteria count observed in sheep fed dietary treatments 1 and 4, respectively. Rumen fungi count were relatively similar $(\mathrm{p}>0.05)$ across treatment groups, except for the marginal numerical differences of fungi count between sheep fed diets $2\left(0.30 \times 10^{5}\right.$ $\mathrm{cfu} / \mathrm{mL})$ and $3\left(0.23 \times 10^{5} \mathrm{cfu} / \mathrm{mL}\right)$, respectively. The variation in numerical fungi count between sheep fed diets $2(0.30$ $\mathrm{x} 105 \mathrm{cfu} / \mathrm{mL})$ and $3(0.23 \mathrm{x} 105 \mathrm{cfu} / \mathrm{mL})$, respectively is a reflection of differences in diets resistance to the reduction in the size of the feed particles for attachment of bacteria and digestion of structural cell walls (Castilo-Gonzalez et al., 2014). Rumen protozoa count was similar $(\mathrm{p}>0.05)$, with a mean population ranging from 3.75 to $4.75 \mathrm{ml} / 100 \mathrm{~mL}$ across the treatment groups. The variation in rumen protozoa population among dietary treatments may be from the dietary levels of starch (Brown et al., 2006) and the rate of starch fermentation (Carberry et al., 2012). The proliferation of rumen microbes for rapid degradation of roughages or fibrous feed is a function of ruminally fermentable dietary nutrients in the ruminal ecosystem (Newbold and Ramos-Morales, 2020). As a result, differences in total microbial biomass in this study could be ascribed to the suitability of the substrate available in the ruminal ecosystem for the proliferation of the microbes.

Table 3: Rumen fermentation characteristics and microbial population of sheep fed mixed ration of crop residues

\begin{tabular}{|c|c|c|c|c|c|c|}
\hline \multirow[b]{2}{*}{ Parameters } & \multicolumn{4}{|c|}{ Dietary roughage treatments } & \multirow[b]{2}{*}{ SEM } & \multirow[b]{2}{*}{ P-value } \\
\hline & TI & T2 & T3 & T4 & & \\
\hline Rumen $\mathrm{pH}$ & 6.14 & 6.05 & 6.20 & 6.17 & 0.03 & 0.2679 \\
\hline $\begin{array}{l}\text { Total volatile fatty acids } \\
(\mathrm{mmol} / \mathrm{mL})\end{array}$ & 134.75 & 258.50 & 157.00 & 269.50 & 27.21 & 0.1848 \\
\hline Acetic acid $(\mathrm{mmol} / \mathrm{mL})$ & 89.50 & 172.00 & 105.25 & 179.50 & 18.17 & 0.1897 \\
\hline Propionic acid (mmol/mL) & 1111.3 & 2109.5 & 1296.0 & 2219.0 & 222.86 & 0.1906 \\
\hline Butyric acid (mmol/mL) & 1805.0 & 1398.0 & 1543.0 & 2642.8 & 304.10 & 0.5152 \\
\hline $\mathrm{NH}_{3}-\mathrm{N}(\mathrm{mg} / 100 \mathrm{~mL})$ & $9.61^{\mathrm{ab}}$ & $8.51^{\mathrm{c}}$ & $9.28^{b}$ & $10.17^{\mathrm{a}}$ & 0.17 & 0.0004 \\
\hline Bacterial count (cfu/mL x10 $)$ & $1.65^{\mathrm{a}}$ & $1.53^{\mathrm{a}}$ & $1.28^{\mathrm{b}}$ & $1.75^{\mathrm{a}}$ & 0.06 & 0.0047 \\
\hline Fungi count (cfu/mLx $\left.10^{5}\right)$ & $0.28^{\mathrm{ab}}$ & $0.30^{\mathrm{a}}$ & $0.23^{\mathrm{b}}$ & $0.28^{\mathrm{ab}}$ & 0.01 & 0.1522 \\
\hline Protozoa count $(\mathrm{ml} / 100 \mathrm{~mL})$ & 4.00 & 3.75 & 4.50 & 4.75 & 0.17 & 0.1382 \\
\hline
\end{tabular}

$\overline{\mathrm{abc}}=$ Means on the same row with different superscript differ significantly $(\mathrm{p}<0.05)$.

Diet $1=53 \%$ Dried corn cob, 30\% Palm kernel sludge, $12 \%$ Soya bean hull, $4.5 \%$ Gliricidia sepium and $0.5 \%$ Salt; Diet $2=53 \%$ Dried cassava peel, $30 \%$ Palm kernel sludge, $12 \%$ Soya bean hull, $4.5 \%$ Gliricidia sepium and 0.5\% Salt; Diet 3=53\% Groundnut haulm, 30\% Palm kernel sludge, $12 \%$ Soya bean hull, 4.5\% Gliricidia sepium and 0.5\% Salt; Diet 4= 53\% Cowpea husk, 30\% Palm kernel sludge, $12 \%$ Soya bean hull, $4.5 \%$ Gliricidia sepium and $0.5 \%$ Salt. 


\section{A mixed ration of crop residues}

\section{Haematological parameters}

Haematological parameters of sheep fed mixed ration of crop residues are shown in Table 4.There were significant $(\mathrm{p}<0.05)$ differences across the treatments, except for the lymphocytes and neutrophils which were similar. The PCV (52.00\%) and (Hb) $(16.95 \mathrm{~g} / \mathrm{dL})$ values of sheep fed diet 4 were above the normal range $(27-45 \%$ and 9$15 \mathrm{~g} / \mathrm{dL})$. However, the range of PVC (33.00-45.00\%), $\mathrm{Hb}(10.65-14.65 \mathrm{~g} / \mathrm{dL})$ and RBC $\left(11.79-14.2 \times 10^{6} / \mu 1\right)$ of sheep fed diets 1,2 and 3 , respectively were within the normal range $(27-45 \%, 9-15 \mathrm{~g} / \mathrm{dL}$ and $9-15$ $\mathrm{x} 10^{6} / \mu 1$ ), reported by Radostits et al. (2007) for clinically healthy sheep. The high packed cell volume (PCV), haemoglobin $(\mathrm{Hb})$, red blood cell (RBC) values observed in this study is an indication of the absence of anaemic condition and active erythropoiesis across all the experimental sheep. The higher $\mathrm{Hb}$ and $\mathrm{PCV}$ values above the normal physiological range observed for sheep fed diet 4 may not directly indicate a relative polycythaemic condition as observed from the relationship between PCV and haemoglobin (MCHC). Although dietary and serum copper $(\mathrm{Cu})$ levels were not assayed, the range of $\mathrm{Hb}$ and RBC values observed across the treatment groups may be from the residual $\mathrm{Cu}$ content in palm kernel sludge, a component of the diets. Palm kernel sludge is a by-product of palm kernel cake processing during palm kernel oil extraction. Palm kernel cake is relatively high in copper and iron (Duduyemi et al.,2016). Therefore, the $\mathrm{Cu}$ content in the diet may have contributed to the formation of red blood cells. Functional roles of serum copper among others are in erythropoiesis and production of coppercontaining mitochondrial proteins for haem synthesis (Williams et al., 1985).

The white blood cell was highest $(8.43 \mathrm{x}$ $\left.10^{3} / \mu \mathrm{l}\right)$ in dietary treatment 2 and lowest $\left(6.55 \times 10^{3} / \mu 1\right)$ in sheep fed diet 4 . The lymphocytes and neutrophils count varied from $59.50-63.50 \%$ and $32.50-35.00 \%$, respectively across the treatments. The nonsignificance of WBC, lymphocyte and neutrophil counts of experimental animals across the treatments, which are within the normal physiological ranges $(\mathrm{WBC}=5.00$ to $11.00 \times 10^{6} / \mathrm{dL}$, lymphocytes $=40-75 \%$ and neutrophil $=10-50 \%$ ) reported for healthy sheep (Scott et al. 2006; Radostits et al., 2007), implies that the sheep had similar immune response against infections. Further attested by the high lymphocytes and neutrophils is also an indication of a well-developed immune system that is capable of fighting infections and the presence of foreign bodies in the circulatory system. Sheep fed tannin-rich feeds have been implicated in the reduction of WBC and white blood cells differential counts (Mahgoub et al., 2008). The lymphocyte and neutrophil counts observed in this study are suggestive that the experimental diets did not contain toxic or anti-nutritional substances that could result in low WBC count.

\section{Serum biochemical profiles}

Serum biochemical values were significant $(\mathrm{p}<0.05)$, except a s partate aminotransferase (AST) and creatinine that were similar $(p>0.05)$ (Table 5). Serum total protein across the treatments ranged from 8.68 to $9.78 \mathrm{~g} / \mathrm{dL}$ and were significantly different $(\mathrm{p}<0.05)$. In this study, serum total protein of 8.68 to $9.78 \mathrm{~g} / \mathrm{dL}$ was not comparable to values of serum protein $(6.4$ to 8.3 and 5.81 to $6.36 \mathrm{~g} / \mathrm{dL}$ ) reported for Nigerian and Ethiopian breeds of sheep respectively (Njidda et al., 2014; Ayele et al., 2017). Serum protein above the normal range (6.0-7.9 g/dL) reported by Kaneko et al. (2008) among the sheep might be attributed to greater efficiency of dietary protein utilization. Albumin values among sheep fed diets 1 to 3 respectively, were within the normal range of 2.4-3.0 g/dL reported by Kaneko et al. (2008). Serum albumin is a highly sensitive and nutritional 
Omotoso, Ajayi, Boladuro and Emerue

Table 4: Haematological parameters of sheep fed mixed ration of crop residues

\begin{tabular}{|c|c|c|c|c|c|c|}
\hline \multirow[b]{2}{*}{ Parameters } & \multicolumn{4}{|c|}{ Dietary roughage treatments } & \multirow[b]{2}{*}{ SEM } & \multirow[b]{2}{*}{ P-value } \\
\hline & T1 & $\mathbf{T 2}$ & T3 & T4 & & \\
\hline Packed cell volume (\%) & $33.00^{\mathrm{b}}$ & $43.50^{\mathrm{a}}$ & $45.00^{\mathrm{a}}$ & $52.00^{\mathrm{a}}$ & 2.29 & 0.0116 \\
\hline Haemoglobin $(\mathrm{g} / \mathrm{dL})$ & $10.65^{\mathrm{b}}$ & $14.20^{\mathrm{a}}$ & $14.65^{\mathrm{a}}$ & $16.95^{\mathrm{a}}$ & 0.78 & 0.0163 \\
\hline Red blood cells $\left(\times 10^{6} / \mu \mathrm{l}\right)$ & $11.79^{\mathrm{b}}$ & $12.84^{\mathrm{ab}}$ & $13.29^{\mathrm{a}}$ & $14.25^{\mathrm{a}}$ & 0.31 & 0.0174 \\
\hline MCHC (\%) & 32.27 & 32.64 & 32.56 & 32.60 & 0.07 & 0.2069 \\
\hline White blood cells $\left(\mathrm{x} 10^{3} / \mu \mathrm{l}\right)$ & $7.40^{\mathrm{ab}}$ & $8.43^{\mathrm{a}}$ & $6.65^{\mathrm{b}}$ & $6.55^{\mathrm{b}}$ & 0.27 & 0.0272 \\
\hline Lymphocytes (\%) & 63.50 & 62.00 & 59.50 & 61.00 & 0.99 & 0.5786 \\
\hline Neutrophils (\%) & 32.50 & 33.50 & 34.00 & 35.00 & 0.79 & 0.7686 \\
\hline
\end{tabular}

$\mathrm{abc}=$ Means on the same row with different superscripts are significantly different $(\mathrm{p}<0.05)$.

$\mathrm{MCHC}=$ Mean corpuscular haemoglobin concentration. Diet 1=53\% Dried corn cob, 30\% Palm kernel sludge, $12 \%$ Soya bean hull, $4.5 \%$ Gliricidia sepium and $0.5 \%$ Salt; Diet $2=53 \%$ Dried cassava peel, $30 \%$ Palm kernel sludge, $12 \%$ Soya bean hull, $4.5 \%$ Gliricidia sepium and $0.5 \%$ Salt; Diet 3=53\% Groundnut haulm, 30\% Palm kernel sludge, 12\% Soya bean hull, 4.5\% Gliricidia sepium and 0.5\% Salt; Diet 4= 53\% Cowpea husk, 30\% Palm kernel sludge, 12\% Soya bean hull, 4.5\%Gliricidia sepium and $0.5 \%$ Salt.

indicator of protein status (Agenas et al., 2006) and predisposition of animals to diseases. Interestingly, higher serum protein levels observed is an indication of the absence of proteinuria and hypoproteinemia (Kaneko et al., 2008). The higher albumin value $(4.36 \mathrm{~g} / \mathrm{dL})$ observed for sheep fed diet 4 though was above the normal value as reported (Kaneko et al., 2008), might be indicative of the synthetic ability of the liver and the crude protein $(17.33 \%)$, which is above the $14.48 \% \mathrm{CP}$ recommended for growing sheep (NRC, 2007).Globulin levelof sheep fed diet 4 $(5.42 \mathrm{~g} / \mathrm{dL})$ was statistically similar $(\mathrm{p}>0.05)$ to the value $(6.19 \mathrm{~g} / \mathrm{dL})$ recorded for dietary treatment 3 . The varied serum globulin levels (5.42 to $6.92 \mathrm{~g} / \mathrm{dL})$ which is above the normal physiological range (3.5$5.7 \mathrm{~g} / \mathrm{dL}$ ) prescribed by Kaneko et al. (2008), except for sheep on diet 4 $(5.42 \mathrm{~g} / \mathrm{dL})$ is suggestive of the absence of malnutrition and congenital immune deficiency (Busher 1990) among the experimental animals.Serum glucose concentration of sheep fed diet 2 (94.83 $\mathrm{mg} / \mathrm{dL})$ and diet $4(61.21 \mathrm{mg} / \mathrm{dL})$ agrees with the normal ranges of 55.0-131.00 $\mathrm{mg} / \mathrm{dL}$ and $50-80 \mathrm{mg} / \mathrm{dL}$ reported by Radostits et al. (2007) and Latimer (2011), respectively. However, high serum glucose concentration observed in sheep fed diets 2 and 4 respectively, does not suggest hyperglycemia condition as they are within the reported normal range (Radostits et al., 2000; Latimer, 2011). Meanwhile, the significantly lower blood glucose levels detected in sheep fed diets $1(32.68 \mathrm{mg} / \mathrm{dL})$ and $3(41.38 \mathrm{mg} / \mathrm{dL})$, respectively, compared to the normal range could be a manifestation of carbohydrate deficiency. The hypoglycemic condition could also be associated with a lower rate of recovery of glucose (Radostits et al., 2000). It follows that significant variations in serum glucose levels observed across the treatment groups may be reflective of the dietary energy levels, intake and metabolism by individual animals. The range of cholesterol levels $(15.50-22.39 \mathrm{mg} / \mathrm{dL})$ among the treatments was below the normal ranges of 43-103 $\mathrm{mg} / \mathrm{dL}$ and $52-76 \mathrm{mg} / \mathrm{dL}$ reported by Radostits et al. (2007) and Kaneko et al. (2008) respectively. The extremely low cholesterol levels compared to the reference range of $52-76 \mathrm{mg} / \mathrm{dL}$ (Kaneko et al., 2008) implies that experimental animals were healthy and not vulnerable to myocardial infractions caused by the blockage of walls of blood vessels. Therefore, crop residues 


\section{A mixed ration of crop residues}

based diets for ruminants, being low in soluble carbohydrates and energy could reduce the deposition of fats in tissues. The creatinine concentrations (1.45-2.00 $\mathrm{mg} / \mathrm{dL}$ ) across the treatments were within the normal range $(1.00-2.00 \mathrm{mg} / \mathrm{dL})$ reported by Banerjee (2006) but disagreed with $1.61-1.89 \mathrm{mg} / \mathrm{dL}$ reported for sheep by Jiwuba et al. (2017). The creatinine levels observed across the treatments are indicative of normal renal function, which could have resulted from efficient protein and amino acid metabolism (Abu El-Ella and Kommonna, 2013), absence of tissue protein catabolism (Prvulovic et al., 2012) and anti-nutritional factors in the diets. The serum urea values ranged from 20.62 to $23.49 \mathrm{mg} / \mathrm{dL}$ across the treatments and falls within the normal range (10-35 $\mathrm{mg} / \mathrm{dL})$ reported by Radostits et al. (2000). Meanwhile, serum urea values in this study were not in agreement with the range ( 11.73 to $18.24 \mathrm{mg} / \mathrm{dL}$ ) of serum urea values reported by Alves et al. (2014) who evaluated diets with increasing levels of urea in sheep feeding. Within the normal range of serum urea observed in this studyis an indication of efficient utilisation of dietary nitrogen (Alves et al., 2014). However, higher serum urea nitrogen observed in sheep fed diet 1 despite the low crude protein content $(5.20 \mathrm{~g} / 100 \mathrm{~g}$ DM) may be a result of the increased catabolic activity for increased gluconeogenesis or excessive tissue protein breakdown (Radostits et al., 2000). Serum enzyme activity can be used to predict the severity of injury to hepatic cells. In this study, the low levels of serum activity of liver enzymes (ALT, AST and ALP), below normal physiological ranges reported (Radostits et al., 2000; Kaneko et al., 2008; Latimer, 2011) implies that no hepatocellular damage occurred in the animals. This is an indication of no toxic effect of experimental diets upon ingestion by the animals on the liver or muscles due to optimal renal and hepatic functions.

Table 5: Serum parameters of sheep fed mixed ration of crop residues

\begin{tabular}{lllllll}
\hline & \multicolumn{5}{c}{ Dietary roughage treatments } & \\
\cline { 2 - 5 } Parameters & T1 & T2 & T3 & T4 & SEM & P-value \\
\hline Total protein (g/dL) & $9.61^{\mathrm{a}}$ & $9.06^{\mathrm{b}}$ & $8.68^{\mathrm{b}}$ & $9.78^{\mathrm{a}}$ & 0.14 & 0.0033 \\
Albumin (g/dL) & $2.69^{\mathrm{b}}$ & $2.42^{\mathrm{b}}$ & $2.49^{\mathrm{b}}$ & $4.36^{\mathrm{a}}$ & 0.23 & 0.0002 \\
Globulin (g/dL) & $6.92^{\mathrm{a}}$ & $6.64^{\mathrm{a}}$ & $6.19^{\mathrm{ab}}$ & $5.42^{\mathrm{b}}$ & 0.21 & 0.0331 \\
ALT (IU/L) & $7.80^{\mathrm{b}}$ & $8.48^{\mathrm{b}}$ & $9.92^{\mathrm{a}}$ & $8.64^{\mathrm{b}}$ & 0.23 & 0.0011 \\
AST (IU/L) & 21.31 & 24.00 & 26.13 & 20.69 & 1.11 & 0.2947 \\
ALP (IU/L) & $52.43^{\mathrm{c}}$ & $64.25^{\mathrm{a}}$ & $53.94^{\mathrm{bc}}$ & $59.24^{\mathrm{ab}}$ & 1.50 & 0.0049 \\
Cholesterol (mg/dL) & $22.39^{\mathrm{a}}$ & $15.46^{\mathrm{b}}$ & $22.16^{\mathrm{a}}$ & $16.14^{\mathrm{b}}$ & 1.05 & 0.0051 \\
Glucose (mg/dL) & $32.68^{\mathrm{d}}$ & $94.83^{\mathrm{a}}$ & $41.38^{\mathrm{c}}$ & $61.21^{\mathrm{b}}$ & 6.23 & $<.0001$ \\
Creatinine (mg/dL) & 1.55 & 1.80 & 2.00 & 1.45 & 0.09 & 0.1301 \\
Urea (mg/dL) & $23.49^{\mathrm{a}}$ & $20.62^{\mathrm{b}}$ & $21.48^{\mathrm{b}}$ & $20.89^{\mathrm{b}}$ & 0.39 & 0.0201 \\
\hline
\end{tabular}

$\overline{\mathrm{abc}}=$ Means on the same row with different superscript differ significantly $(\mathrm{p}<0.05)$.

$\mathrm{AST}=$ Aspartate aminotransferase; ALT $=$ Alanine transferase; ALP $=$ Alkaline phosphatase. $\quad$ Diet $1=$ $53 \%$ Dried corn cob, 30\% Palm kernel sludge, $12 \%$ Soya bean hull, 4.5\% Gliricidia sepium and 0.5\% Salt; Diet 2=53\% Dried cassava peel, 30\% Palm kernel sludge, 12\% Soya bean hull, 4.5\% Gliricidia sepium and $0.5 \%$ Salt; Diet 3=53\% Groundnut haulm, 30\% Palm kernel sludge, $12 \%$ Soya bean hull, $4.5 \%$ Gliricidia sepium and $0.5 \%$ Salt; Diet 4= 53\% Cowpea husk, 30\% Palm kernel sludge, $12 \%$ Soya bean hull, $4.5 \%$ Gliricidia sepium and $0.5 \%$ Salt. 


\section{Conclusion}

The study revealed that crop residues based-diets from different roughage sources influenced ruminal fermentation characteristics of sheep as evidenced in the ruminal ammonia nitrogen concentration and microbial counts higher in rumen protozoan. Also, butyric and propionic acids were of higher proportions than acetic acid in the rumen. Haematological and serum biochemical parameters were similar to normal reference values for apparently healthy sheep. Therefore, mixed ration of crop residues have no negative impact on the ruminal activities and health of West African dwarf sheep and can be strategically utilised as dry season feed in smallholder sheep production system.

\section{References}

Abu El-Ella, A. A. and Kommonna, O. F. 2013. Reproductive performance and blood constituents of Damascus goats as affected by yeast culture supplementation. Egyptian Journal of Sheep Goat Sciences 8: 171-187.

Adesogan, A. T., Arriola, K. G., Jiang, Y., Oyebade, A., Paula, E. M., PechCervantes, A. A. Romero, J. J., Ferraretto, L. F. and Vyas, D. 2019. Symposium review: Technologies for improving fibre utilization. Journal of Dairy Science. 102:5726-5755

Agenas, S., Heath, M. F., Nixon, R. M., Wilkinson, J. M. and Phillips, C. J. C. 2006. Indicators of undernutrition in cattle. Animal Welfare. 15(2): 149-160.

Ajayi, F. T.,Omotoso, S. O. Taiwo, A. A. and Ajayi, D. A. 2019. Growth and nutrient digestibility of West African Dwarf (WAD) sheep fed crop residue-based concentrate and unripe plantain peel. Moor Journal of Agricultural Research. 20
(2):138-150.

Allain, C. C., Poon, L. S., Chan, W. R. and Fu, P. C. 1974. Enzymatic determination of total serum cholesterol. Clinical Chemistry. 20: 470-475.

Alves, E. M., Magalhaes, D. R., Freitas, M. A., Santos, E. J., Pereira, M. L. A. and Pedreira, M. S. 2014. Nitrogen metabolism and microbial synthesis in sheep fed diets containing slow-release urea to replace the conventional urea. Acta ScientiarumAnimal Sciences. 36(1): 55-62.

Aregheore, E.M. 2000. Chemical composition and nutritive value of some tropical by-product feedstuffs for small ruminantsin vivo and in vitro digestibility. Animal Feed Science and Technology. 85 (1-2): 99-109.

Aschenbach J. R., Penner, G. B., Stumpff, F. and Gabel, G. 2011. Ruminant nutrition symposium: role of fermentation acid absorption in the regulation of ruminal pH. Journal of Animal Science. 89:1092-1107.

Association of Official Analytical Chemists. (AOAC). 2000. Official Methods of Analysis. 17th ed. Arlington, VA, USA.

Ayele, S., Urge, M., Animut, G. and Yusuf. M. 2017. Feed intake, digestibility, growth performance and blood profiles of three Ethiopian fat tail hair sheep fed hay supplemented with two levels of concentrate supplement. Open Journal of Animal Sciences. 7: 149167.

Babayemi, O. J. and Bamikole, M. A. 2006. Effects of Tephrosia candida leaf and its mixtures with guinea grass on in vitro fermentation changes as feed for ruminants in 


\section{A mixed ration of crop residues}

Nigeria. Pakistan Journal of Nutrition. 5(1):14-18.

Banerjee, G. C. 2006. A Textbook on Animal Husbandry. 8th Edition. Oxford and IBH Publishing Co. Pvt. Ltd, New Delhi. Pp1079.

Bergman, E. N. 1990. Energy contributions of volatile fatty acids from the gastrointestinal tract in various species.Physiological Reviews. 70(2):567-590.

Bhatt, R. S., Agrawal, A. R. and Sahoo, A. 2014 . In-vitro ruminal degradability, fermentation metabolites and methanogenesis of different crop residues.Animal Nutrition and Feed Technology. 14: 337-348.

Bonsnes, R. W. and Taussky, H. H. J. 1945. Determination of creatinine in plasma and urine. Journal of Biochemistry. 58: 581-589.

Brown, M. S., Ponce, C. H. and Pulikanti, R. 2006. Adaptation of Beef Cattle to High-Concentrate Diets: Performance and Ruminal Metabolism. Journal of Animal Science. 84:25-33.

Busher, J. T. 1990. Serum albumin and globulin: In clinical methods, the history, physical, and laboratory examinations. 3rd edition. Boston: Butterworths. Chapter 101.

Carberry, C. A., Kenny, D. A., McCabe, S., McCabe, M. S. and Waters, S. M. 2012. Effect of phenotypic residual feed intake and dietary forage content on the rumen microbial community of beef cattle. Applied Environmental Microbiology. 78: 4949-4958.

Castillo-Gonzaleza, A. R., BurrolaBarrazab, M. E., DominguezViverosb, J., and ChavezMartinez, A. 2014. Rumen microorganisms and fermentation. Archival Medical Veterinary. 46:
349-361.

Dacie, J. V. and Lewis, S. M. 2001. Practical Haematology. 11th Edition, Longman Group. Ltd. Hong Kong. pp 11-17.

De Boever, J. L., Cottyn, B. G., De Brabandar, D. L., Vanacker, J. M. and Boucque, C. V. 1997. Prediction of the feeding value of maize silage by chemical parameters, in-vitro digestibility and near infra-red spectroscopy (NIRS). Animal Feed Science Technology. 66:211-222.

Dehority, B. A. 2003. Rumen microbiology: introduction to micro-organisms in the rumen, their activities and interactions in the digestion of plant materials. Nottingham University Press, UK. 372pp.

Detmanna, E., Paulinoa, M. F., Mantovani, H. C., Valadares Filhoa, S. C., Sampaio, C. B. de Souza, M. A., Lazzarini, I. and Detmann, K. S. C. 2009. Parameterization of ruminal fibre degradation in low-quality tropical forage using Michaelis-Menten kinetics. Livestock Science. 126:136-146.

Duduyemi, O., Ogundipe, K. O. and Olajide, J. O. 2016. Analyses of copper concentrations in palm kernel cake from three industrial palm kernel oil mills. Journal of Engineering Technology. 10(2):115-120.

Firkins, J. L., Hristov, A. N., Hall, M. B., Varga, G. A. and St-Pierre, N. R. 2006. Integration of ruminal metabolism in dairy cattle. Journal of Dairy Science. 89: 31-51.

Galyean, M. 1989. Laboratory Procedure in Animal Nutrition Research. Department of Animal and Life Sciences. New Mexico State 
University, USA.

Gilchrist Shirlaw, D.W. 1967. Proximate Analysis of Feed and Feedstuff. In: A Practical Course in Agricultural Chemistry. Gilchrist Shirlaw, D. W., and Nichols, J. E. (1967). A volume in the Commonwealth and International Library: Agriculture and Forestry Division. Pergamon Press Limited. pp. 112-141.

Gulilat, L. and Chekol, Y. 2020. Mineral in crop residues and interaction with soil minerals contents in Ethiopia: a review. Food Processing and Technology. 8(2):40-44.

Haddad, S. G. and Grant, R. J. 2000. Influence of non-fibre carbohydrate concentration on forage fibre digestion in-vitro. Animal Feed Science and Technology 86:107-115.

Helmut, J. R. and Yvette, S. L. 1959. A simple method for the determination of blood urea nitrogen, with special automatic colourimeter analysis. Clinical Chemistry. 5: 617-620.

Jain, N. C. 1993. Essentials of Veterinary Haematology 6th Edition. Lea and Febiger, Malvern, Pennsylvania, U.S.A.

Jiwuba, P. C., Jiwuba, L. C. and Onyekwere, M. U. 2017. Growth performance, haematology and serum biochemistry of West African dwarf sheep fed cassava peel-oil palm leaf meal-based diets in hot humid tropics. Agricultural/ 14 (1-2): 37-44.

Kaneko, J. J., Harvey, W. J. and Bruss, M. L. 2008. Clinical biochemistry of domestic animals. 6th Edition. Academic Press. Pp928.

Klopfenstein, T. J., Mass, R. A., Crighton, K. W. and Pattern, $\mathbf{H}$. H. 2001. Estimating forage and protein degradation in the rumen. Journal of Animal Science .79: 208-217.

Kohn, R.A. and Allen, M. S. 1995. Enrichment of proteolytic activity relative to nitrogen in preparation from the rumen for in-vitro studies. Animal Feed Science Technology. 52 (1-2): 1-14.

Konka, R. K., Kumar, D. S., Ramana, J. V., Ravi, A. and Rao, E. R. 2016. Fermentation pattern in Murrah buffalo bulls fed crop residuebased complete rations vis-a-vis conventional feeding system. Animal Nutrition Feed Technology. 16(1): 171-179.

Krause K. M. and Oetzel, G. R. 2006. Understanding and preventing subacute ruminal acidosis in dairy herds: a review. Animal Feed Science Technology 126: 215-236.

Kucuk, O., Hess, B. W., Ludden, P. S. and Rule, D. C. 2003. Effects of Increasing Dietary Forage in Limited-Fed Ewes fed a 6\% Fat Diet. Sheep and Goat Research Journal. 18:25-33.

Latimer, K. S. 2011. Duncan and Prasse's Veterinary Laboratory Medicine: Clinical Pathology, 5th Edition. Wiley-Blackwell. pp528.

Leng, R. A. 1990. Factors affecting the utilization of poor-quality forages by ruminants particularly under tropical conditions. Nutrition Research and Review. 3:277-303.

Li, R. W., Wu, S. R., Baldwin, L., Li, W. and Li, C. 2012. Perturbation dynamics of the rumen microbiota in response to exogenous butyrate. PLoS One 7: e29392.

Mahgoub, O., Kadim, I. T., Tageldin, M. H., Al-Marzooqi, W., Khalaf, S. K. and Ali, A. A. 2008. Clinical profile of sheep fed nonconventional feeds containing 


\section{A mixed ration of crop residues}

phenols and condensed tannins. Small Ruminant Research. 78: $115 \# 122$.

Meissner, H. H., and Paulsmeier, D. V. 1995. Plant compositional constituents affecting betweenplant and animal species prediction of forage intake. Journal of Animal Science. 73: 2447-2457.

Nathani, N. M., Patel, A. K., Mootapally, C. S., Reddy, B., Shah, S.V., Lunagaria, P. M., Kothari, R. K. and Joshi, C. G. 2015. Effect of roughage on rumen microbiota composition in the efficient feed converter and sturdy Indian Jaffrabadi buffalo (Bubalus bubalis). BMC Genomics. 16: 1116.

National Research Council. 2007. Nutrient requirements of small ruminants: sheep, goats, cervids, and new world camelids. National Academy of Sciences, Washington, DC, 20001. Pp 384.

Newbold, C. J. and Ramos-Morales, E. 2020 . Review: Ruminal microbiome and microbial metabolome: effects of diet and ruminant host. Animal. 14: 78-86.

Njidda, A. A., Shuai'bu, A. A. and Isidahomen, C. E. 2014. Haematological and serum biochemical indices of sheep in the semi-arid environment of Northern Nigeria. Global Journal of Science Frontier Research .14 (2): 48-55.

Palmonari, A., Stevenson, D. M., Mertens, D. R., Cruywagen, C. W. and Weimer, P. J. 2010. The $\mathrm{pH}$ dynamics and bacterial community composition in the rumen of lactating dairy cows. Journal of Dairy Science. 93: 279287.

Prvulovic, D., Slavica, K., Milan, P., Dimitrijevic, D. and Grubor-
Lajsic, G. 2012. The influence of hydrated aluminosilicate on biochemical and haematological blood parameters, growth performance and carcass traits of pigs. Journal of Animal and Veterinary Advances. 11(1): 134140.

Radostits, O. M., Mayhew, I. G. and Houston, D. M. 2000. Veterinary Clinical Examination and Diagnosis. W.B. Saunders, London.

Radostits, O.M., Gay, C. C., Hinchclif, K. W. and Constable, P. D. 2007. Veterinary medicine: a textbook of the disease of cattle, sheep, goats, pigs and horses. Saunders, Edinburgh, USA. 10th Edition. Pp 2065.

Rao, P. and Hall, A. J. 2003. Importance of crop residues in crop-livestock systems in India and farmers' perceptions of fodder quality in coarse cereals. Field Crops Research. 84: 189-198.

SAS (Statistical Analysis Systems Institute Inc.). 1999. SAS for Windows, Version 8, Cary, NC, USA.

Schalms, O. W., Jane, N. C. and Carot, E. J. 1975. Veterinary Haematology. Lea and Febiger, Philadelphia pp. 15-18.

Scott, J. L., Ketheesan, N. and Summers, P. M. 2006. Leucocyte population changes in the reproductive tract of ewe in response to insemination. Reproduction Fertility and Development. 18: 627-634.

Tingshuang, G., Sánchez, M. D. and Yu, G. P. 2002. Composition, nutritive value and upgrading of crop residues. In: animal production based on crop residues- Chinese experiences. FAO Animal Production and Health Paper 149. 
Van Soest, P. J., Robertson, J. B. and Lewis, B. A. 1991. Methods for dietary fibre, neutral detergent fibre, and non-starch polysaccharides in relation to animal nutrition. Journal of Dairy Science. 74: 3583-3597.

Varley, H., Gowelock, A. H. and Bell, M. 1980. Determination of serum protein using the acetyl monoxide method: Practical biochemistry. 5th Edition. London: William Heinemann Medical Books Ltd.

Williams, D.M., Kennedy, F. S. and Green, B. G. 1985. The effect of iron substrate on mitochondrial haem synthesis in copper deficiency. British Journal of Nutrition. 53(1):131-136.

Received: 6 $^{\text {th }}$ August, 2021

Accepted: $10^{\text {th }}$ December, 2021 